\title{
Naturalist Methods in the Sociology of Creation: The Case Against Reductionism
}

\author{
Dafne Muntanyola-Saura \\ UNIVERSITAT AUTÒNOMA DE BARCELONA \\ dafne.muntanyolađauab.cat \\ ORCID: 0000-0002-2684-9577
}

Received: 28/04/2020

Accepted: 17/03/2021

\begin{abstract}
The Sociology of Culture has much to say when it comes to the ever-changing general consensus on what constitutes legitimate culture and definitions of creativity. The naturalistic studies on cognition in social and cognitive sciences show this empirically (Bourdieu, 1979: Becker, 1982, 2002; Sennett, 2012; Author, 2014). Creative cognition is part of an institutional context. However, the influential culturalist branch of cognitive sociology (CCS) reduces creativity to a cognitivist psychological level (Lizardo and Strand, 2010). We start from the conjecture that the Sociology of Culture can draw on the naturalistic paradigm of cognition to explain creativity without falling into reductionist or atomist positions. The authors take the diversity of theoretical-empirical proposals into account in identifying the starting points for focusing the debate at both the macro and micro levels. The body of the article comprises a literature review which, while not exhaustive, offers a full picture of the pragmatic and integrated models of creativity. The studies analysed present inter-subjective processes of creation and the transmission of variable legitimate criteria concerning cultural consumption such as categorisations, evaluations and aesthetic judgments. The sociological perspective offers scope for strengthening critical tools for examining creativity.
\end{abstract}

Keywords: sociology of culture, legitimacy, taste, ethno-methodology, Lizardo, Bourdieu.

Corresponding author: Dafne Muntanyola-Saura. Departamento de Sociología. Edificio B, Calle de la Fortuna. Campus de la UAB 08193 Bellaterra. Cerdanyola del Vallès (Spain).

Suggested citation: Muntanyola-Saura, D. (2021). Naturalist Methods in the Sociology of Creation: The Case Against Reductionism. Debats. Journal on Culture, Power and Society, 6, 121-133. DOI: http://doi.org/10.28939/iam.debats-en.2021-8

\section{INTRODUCTION}

We need space to think, debate, read, and create. Here, the Sociology of Culture plays a major role in the ever-shifting consensus on what constitutes legitimate culture and definitions of creativity, meaning that the discipline has a lot to say on the subject. Creative cognition is not just a local psychological product but part of a social context. The Sociology of Culture sees creativity as a phenomenon structured by factors such as gender, social class, and the national framework. Naturalistic studies of cognition in the Social and Cognitive Sciences 
empirically demonstrate that this is so (Bourdieu, 1979: Becker, 1982, 2002; Sennett, 2012; MuntanyolaSaura, 2012, 2014, 2016). We use the term 'naturalist' in the sense found in the philosophical tradition that considers knowledge as a given reality of human and social activity. This is the basis of the sociological perspective and, more specifically, of well-understood Social Constructionism. Yet the influential Culturalist Cognitive Sociology (CCS) school reduces creativity to a cognitivist psychological level (Lizardo and Strand, 2010). CCS sees decision-making as an individual activity that is unconscious and that follows rules that are not directly shaped by social factors. It is assumed that people react automatically to social stimuli in an unsystematic, unreflective fashion. As a result, the CCS perspective considers socialisation and the linguistic and conceptual content of thought to be matters of secondary importance.

This paper starts from the conjecture that the Sociology of Culture might take advantage of the naturalistic paradigm of cognition to explain creativity without falling into reductionist or atomistic positions. The present diversity of theoretical-empirical approaches is taken into account to pin down the starting postulates in each case and to focus the debate at both the macro and micro levels. The paper's goals are to: (1) argue the social construction of creativity; (2) define the socio-historical origin of creativity in three cultural change processes; (3) present the main theoretical schools in Sociology formulating a naturalistic analysis of creativity; (4) gather contributions with a view to understanding specific micro-scale creative practices. The body of this paper therefore consists of a bibliographic review that, while not exhaustive, does cover pragmatic and integrated models of creativity.

\section{THE SOCIAL CONSTRUCTION OF CREATIVITY}

Is creativity an individual or a collective practice? The object of this article is the envelope of creativity - that is to say, the production context of activities that we deem to be creative. A discussion of which neural design makes creativity possible is something that lies beyond the scope of this paper but there are several examples of best-selling neuro-scientists who have addressed the topic, for example Dennett, 1995; Damasio, 1999; Ramachandran and Blackeslee, 1999; Gallese, Keysers and Rizzolatti, 2004. Neither shall we delve into psychological abilities, such as attention or perception either facilitating or hindering that 'Eureka Moment'. Instead, we shall deconstruct the following three strong notions of creativity: (1) the universality of what is considered creativity; (2) the romantic ideal of the creative individual; (3) the reification of creative practice.

First of all, we define creativity as an activity that takes place in the social world, far removed from notions such as instinct, motivation, and inspiration, all of which are psychological processes. From a sociological standpoint, we use the term 'legitimacy' to refer to those social activities accepted and conveyed by the dominant social institutions, and labelled as normal and desirable (Berger and Luckmann, 1995). Creative practice is the legacy of professionals from both the artistic and scientific worlds. Yet creativity is clearly not the sole preserve of these professionals: Merton (1945) stresses that scientific creativity is not only an intentional product but may also arise from happy chance. Furthermore, creativity is not a scarce commodity but rather as Becker (2017) notes, is an inherent feature of social practice in any institutional setting. Joas (1996) puts it slightly differently, arguing that creativity does not exist without the inter-subjectivity of socially organised action. Yet it is also true that some professional practices are socially legitimised as creative while others not. From a sociological standpoint, this gives scope for exploring the conventions for deciding what constitutes art - as Becker (1982) also states. In Bourdieusian terms, not every creative practice is likely to be considered cultural capital.

We could also talk about associated terms such as innovation and entrepreneurship, which link creativity with technology in the first case and with private enterprise in the second. For example, if one uses the search terms 'creativity' and 'innovation' 
in Google, two hits come up on creativity and schooling, the third covers a Post-Graduate Degree on Entrepreneurship, Creativity, and Interdisciplinary Innovation - a course taught by Barcelona University's (UB) Business Studies and Economics Faculty. The Post-Graduate programme is presented thus:

Competitiveness often involves the ability to devise and manage interdisciplinary projects that spawn new markets and provide key differentiation to consolidate projects. This graduate programme delves deeper into the links between creativity and innovation. The overall aim is to impart the basic knowledge, skills and competencies to develop innovative projects through collaborative work and the use of creative tools.

As Becker (1982) so compellingly argues, the labelling process lets us perform this semantic deconstruction. Therefore, creativity here is a competence acquired in a formal education environment linked to the Capitalist market with the aim of boosting business competitiveness. It is a conception legitimised by the university's curriculum, which enshrines a vision that is far removed from artistic notions of creativity. Therefore, the first key idea is that the polysemy of creativity is the product of processes for building social legitimacy.

The second idea is that the social imaginary associates creativity with the ivory tower of the romantic genius, the artist who shuts himself in the studio and is creative despite others, not thanks to them. This was the great myth of modernity, which Paul Feyerabend (1987) attacked, arguing that it is a misconception that has persisted since the nineteenth century. The philosopher was the author of the famous treatise Against Method: Outline of an Anarchistic Theory of Knowledge. In that work, Feyerabend showed science as an opaque, individualistic institution. Years later, in Creativity: A Dangerous Myth (1987) — a lesser-known paper that condenses an alternative view on the subject - he argues that modern creativity does not spring from a social vacuum (confined, as it were, to a given artist's or scientist's brain). According to Feyerabend, creativity as a practice occurs under certain material and historical conditions, with a random component of a procedural and a cumulative nature. Feyerabend comments on the case of Renaissance craftsmen who worked within a given political structure the Tuscan cities. These craftsmen were funded by a patron and their social worth was gauged by their mastery of design, materials, and tools. What is the modern equivalent? Schools and universities should foster the creativity of those who work or study within their walls. The Escola 21 [Schools 21] plan for teaching renewal and the growth of free schools is an example of public awareness of the need for settings that nurture creativity through proper training of teachers, teaching methods, and resourcing.

The third main idea is that we cannot freeze creativity and give it just one meaning. That is because in practice creativity must always be seen in relation to a given society, moment, and age. We cannot pin down the ability to create, to be free, to imagine, or to have new ideas to any one curriculum, architectural style, or trend. Feyerabend does not deny the existence of taste or aesthetic judgment. However, he does stress that reifying cultural output from a given period and taking it as a model is a mistake often made in both academic and lay circles. Reification affects other central concepts in the Social Sciences, such as culture. Here, Mario Bunge distinguishes between an empirical conception and an idealised construction of these cultural practices:

The culture of an advanced society is made up of a large number of subsystems, such as professional groups, the film industry, churches and publishing houses. This (sociological) characterisation contrasts with the idealised concept of culture as a collection of bodiless objects, such as Morality, Art, or Religion per se without regard to the people who produce or consume culture or to their beliefs, artistic mores, and religious practices (Bunge, 2018).

Over time, the ways artists work, present themselves, and the sources of their legitimacy have all changed, as have the forms taken by family relations and Capitalist 
production. The myth of individual creativity begins with the Cartesian dualism between body and mind, matter and spirit, thought and sensation, reason and intuition. As Bruno Latour (1986) states, a 'new man' did not suddenly emerge at some point in the 16th Century. The choice of any given cut-off point is wholly arbitrary, as one can see through the historical comparison of professional settings. Thanks to the contributions made by the French sociologist Pierre Bourdieu (1979, 1984, 1994), we can see just how far the tools for legitimising artistic decisions are professionally constructed. A contemporary artist learns to justify the quality of his work when he knows how to sell it to a potential buyer such as a gallery. To promote himself, he must use the terms that are accepted and shared by those who are part of this field. There is a way of doing this that is learnt by working in the art world, and it takes the form of a habitus, a way of looking, thinking and saying. For example, in everyday life a regular book-buyer will walk through a bookstore, touching the books, looking at them, weighing them up, all behaviours indicative of searching for a certain book, a way of talking to the bookseller, and so on. Thus creativity is an activity that takes shape over time and space, in a changing way, following a socially-defined habitus.

\section{BRIEF SOCIO-HISTORICAL ANALYSIS OF THE PROCESSES OF CULTURAL CHANGE}

The most established sociological approach in Western popular culture is the critique of 'mass culture.' Although the concepts of 'mass society' and 'mass culture' have older roots, they did not play major roles in the analysis of culture and society until the 1930s - roles that were only consolidated until after The Second World War. American and European cultural elites strongly resumed the critique begun in the nineteenth century and based on the perception of a modern world that has diluted the secondary social institutions between the masses on one side and centralised power structures on the other. Prominent members of the Frankfurt School believe that the individual in 'mass society' is alienated and isolated, and is thus prone to being politically manipulated by an authoritarian leader and of being culturally nullified by the machinery of the "cultural industry" (Adorno and Horkheimer, 1972/1994; Ariño and Llopis, 2017). The split between High Culture and popular culture leads to the principle of social hierarchy and to a desire for distinction. This debate is currently at a key juncture in the three processes of social transformation discussed below, namely: commoditisation [turning a good into a commodity]; democratisation; individualisation.

(1) The commoditisation of the cultural industries in the 1950s and 60s marked the collapse of the first project of cultural democratisation, whose goal was to expose the masses to Culture with a capital ' $\mathrm{C}$ ', raising their cultural horizons through public policies. This idea, which at the practical level meant providing schooling and easier access to High Culture, still survives in cultural and artistic circles, legitimising a cultural hierarchy. Yet audiences are becoming more heterogeneous and the market more stratified. Cultural products such as cinema appeal to different publics. This has led to market niches and products catering to different population segments defined by class, status, cultural capital, gender, race and so forth. Thus, the act of cultural consumption becomes the greatest act of social integration. Lipovetsky (2007) defines the values that are starting to take root as those of 'hyper-modernity', in which consumption defines who one is. That is because one defines oneself by what one buys and consumes. Going a step further, the same author together with Serroy (2015), argues that current consumption models have built an ethical and aesthetic duality: on the one hand a speeding up of consumption and life driven by technological progress; on the other, a call for 'down-sizing' in economic, cultural, and emotional terms.

(2) The process of democratisation in the sixties and seventies highlights the limitations of policies fostering broader public access to cultural resources. The consolidation of the 
commoditisation process did not erase social hierarchies or lead to real democratisation. These shortcomings brought criticism on the true scope of access to culture. As a result, modernity suffered a crisis in the late sixties. Bourdieu (1979), among others, evidenced the overlap between cultural and social hierarchies, sex, and age. This critical view questions the notion that 'upper class' tastes are the only legitimate ones, and links the various patterns of cultural consumption to the stations individuals occupy in the social structure. Bourdieu's contribution is a blow to the democratic ideal of culture that had held sway up until then. He revealed the limits of population culturalisation policies, whose impact was much more limited than hoped for by those who drew them up.

The authors of British Cultural Materialism (Williams, 1958, Eagleton, 2000) criticise Liberal Neutralism by stating that culture is above all a normative way of imagining society. Cultural Materialism, moreover, stresses that culture is a material activity rather than an intellectual one. It is a way of giving meaning to the world and the place we occupy in it rather than an end in itself. Instead of 'the masses', there are discourses because cultural forms grow, transform, and diversify. The pessimism of Adorno and Horkheimer (1972) contrasts with the more optimistic view taken in emerging Cultural Studies (Hall and Jefferson, 1975; Stuart Hall, 2007). Here, the Cultural Materialism school of thought argues that creativity exists and works both materially and symbolically as part of the processes forging learning, knowledge, and status.

(3) The progressive individualisation of cultural practices led to an explosion of lifestyles and artistic activities. This process of changing the forms of knowledge, interaction, and being together began with the hedonism of the sixties. These developments in turn drove a host of reflections on the cultural consequences of globalisation in the relationship between power, information and knowledge, and cultural hybridisation (Regev, 2013). Such changes also go some way towards explaining the explosion in the sheer range of tastes expressed on social networks and framed in 'identity' terms. In the field of activism, there have been proposals for seeing cultural democracy through the lens of pro-common or open knowledge movements, and criticisms of the naive drift towards Internet 'cyber-fetishism' (Rendueles, 2013). Yet technology's scope for facilitating access to knowledge is insufficient to sweep away cultural elitism. For this to happen, changes are needed in the social conditions of knowledge production, accompanied. Such changes need to be accompanied by institutional policies for narrowing the digital divide in access to the Internet - (a hot in the scholarly debate on digital literacy).

\section{CRITICAL REVIEW OF CULTURALIST COGNITIVISM}

This section covers the theoretical paradigms of Culturalist Cognitivism, which we consider crucial to understanding the current debates on the legitimacy of creative practices. Indeed, creativity lies at the heart of the clash between reproduction of the hierarchy of cultural capitals and the individualisation of tastes. As Natalie Heinich (1999) notes, avoiding authoritarianism and populism means renouncing the universalism of cultural and artistic production. That is, the bourgeois ideal of art must be renounced for art's sake. Since the 1970s this point led to focus on groups (the so-called iconoclasts): rejecting 'legitimate' culture (1999); consuming non-public culture (Jacobi and Luckerhoff, 2012); or that were inactive in the cultural field (López-Sintas et al, 2014). Vandenberg et al. (2018) analyse the culturally 'illegitimate' practices of Rotterdam's popular music scene, drawing on Bourdieu's field theory and Lizardo and Strand's (2010) dual processing model to this end. The study sought to test whether the dynamics of field distinction take place from the musical orientations verbalised in the survey, or, in the authors' words, as "most common implicit dispositions". 
Leaving aside the descriptive nature of the proposal, this type of research reproduces a confusing cognitivism. The opinions gathered by the survey administered to individuals consuming 'illegitimate' culture were detached from the institutional mechanisms of a relational nature that precisely define their value as a cultural practice. In such an approach, the mechanism of Bourdieu's distinction and reproduction is atomised and the social conditions of legitimation processes are ignored. The definition of legitimacy and illegitimacy, which is the relational product of field conditions in Bourdieu, is reified in this study. The categories or labels of social affiliation are not questioned because the focus of analysis is no longer sociological, becoming psychological and substantialist instead. One of the consequences of this approach is a rigid view of cultural legitimacy in which a dual processing model is harnessed to reproduce a reductionist paradigm. Despite tackling the study an apparently interdisciplinary way, the authors' culturalist view of Cognitive Sociology leads them to analyse creativity in psychological terms. This influential school in Creativity Studies lies at the reductionist end of the reductionism/relationism spectrum, while Becker, Bourdieu, and other authors of the naturalistic sociological perspective at the other end. Lizardo (in Brekhus, 2015) considers Bourdieu's concept of habitus to be a psychological one. He argues that culture is inconsistent, fragmented in its uses and stems from subconscious habit. Yet to claim that everyday knowledge is neither a linguistic nor a symbolic process, and is detached from the process of socialisation is mistaken on two grounds. We can talk of biological mechanisms, such as intentionality (Searle, 2004), second-order reflexivity (Premack, 2004) and conceptual projection (Kirsh, 2009) as factors conditioning habitus. Yet Lizardo's socialisation version (Brekhus, 2015) is a pale version of this idea, in which actors only have a set of freely structured skills, heuristics, routines, and superficial habits that help them navigate (and select) the best strategic actions within an outsourced institutional structure that assumes the least possible "systematicity" at the actor level, with most of the systematicity projected onto the external environment (Lizardo, 2010: 208). Leaving aside that the term 'systematicity' is a purely descriptive one, it is hard to say what level of analysis it covers. The reasoning here is cognitivist, as it falls into a scholastic fallacy, as Bourdieu (1994) would say. The fallacy lies in seeing cognitive processes as the psychological outcome of norms (such as the aforementioned habits and routines) instead of placing such processes in their historically variable contexts. As Lizardo explains later in the same paper, rule following is not linguistic, it is a process based on unconscious mental states. Here, the classic American philosophy authors such as John Searle (2004) and Hubert Dreyfus (1996) brilliantly reveal the fatal flaw in this argument. They point out that every unconscious mental state (following the connectivist principle appearing in Hume's empiricism) should become conscious thought at some point along the way. Since Lizardo denies this possibility, it follows that the heuristic, psychological, individual and mental rules he says lie at the core of our culture and cognition simply do not exist.

The links that Lizardo (2004) forges between Bourdieu and Piaget are relevant and contribute to his heuristic musings on Bourdieu's oeuvre. However, in the same paper (Lizardo: 2004, 395) he states that habitus is an abstract principle, without contextual specificity, a transposable matrix. It is language that recalls the programming principles of GOFAI (Good OldFashioned Artificial Intelligence), that is, the classic models of behaviour-based AI. In other words, Lizardo's cognitivism opens a chasm between neuronal and psychological cognitive processes even though there is none in real life. In the words of Searle (2004), neurons (mirror and others) cause intentional states. It is thanks to the cognitive mechanism of intentionality that we orient ourselves to action and creative judgments. Thus socialisation lies in this interaction between the neural level and the social setting, while the psychological becomes an irrelevant ghost. This is an issue that Cognitive Science has already resolved yet Lizardo seems to be unaware of the fact. This error translates into a superficial interpretation of the process of socialisation and cultural transmission. Brekhus (2015: 18) says that Lizardo considers that direct instruction and socialisation are unnecessary because practices can 
be transmitted and collected unconsciously through the mirror of others.

On the same page, Lizardo summarises Bourdieu's contribution to the interdisciplinary field between Neuroscience, Cognitive Science, and Cultural Sociology in the following terms: These scholars emphasise bodily habits in largely subconscious responses to the environment rather than considering socialisation and language as the main ways in which culture is internalised. This statement falls into the reductionism of confusing neuron interaction with psychological mental states, when in fact it is a relationship between the neural apparatus and the processes of social interaction. By contrast, Berger and Luckmann (1988) spend over 30 pages in The Social Construction of Reality to comment on passages from Alfred Schütz, the New School's social phenomenologist missing from Lizardo's argument. Schütz concisely defines this process of practical, fragmented, and prescriptive knowledge that underpins all cognitive interaction. Berger and Luckmann state that "Schütz mainly focused on analysing the structure of the world of common sense in everyday life" (1988: 31-32). The mechanism of this distribution can be studied through sociological methods.

In short, studies on 'illegitimate' tastes, following Lizardo's cognitivism line, fail to question the definition of survey items as indicators of cultural practices. This perspective leaves out other reflective and relational aspects such as the aforementioned ones. Bourdieu's (1984: 47) perspective, in his own words, is relational and opposes narrow reductionism and atomism:

First, one needs to avoid the tendency to think of the social world in a substantialist way. The notion of space itself embodies a relational notion of the social world: in which 'reality' lies in the mutual exteriority of the elements comprising it. Beings whether they be individuals or groups, exist and subsist in and through difference, which is to say for as long as they occupy relative positions in a field of relationships. Although this field is invisible and hard to empirically demonstrate, it is the most 'real' aspect of our world, underpinning the behaviours of individuals and groups.

Other well-known authors in the field of the Sociology of Culture, such as DiMaggio (1987), propose a compendium of possibilities for interpreting artistic classifications without stating the blindingly obvious. More recently, Johnson, Dowd, and Ridgeway (2006) claim the need for a systematic analysis of de-legitimisation as a social process. Lamont (2010), along with Vlegels and Lievens (2017), analyses the processes of social construction of artistic and musical categories based on classification schemes.

What we raise here is the need for a paradigm shift that does not seek to define creativity in substantive and attributive terms. Creativity is not a property associated with rigid social groups but rather is a relational mechanism. This is an argument already made by Bourdieu in the social sphere and (as reflected in the Anglo-Saxon tradition) is the basis of studies on Popular Culture. Indeed, Raymond Williams 'Cultural Materialism and Stuart Hall's Cultural Turn have highlighted the notion of Popular Culture as the basis for other kinds of legitimacy. It is a question of a hierarchy of legitimacies: The British sociologist Simon Frith (1987) (who was earlier closely linked to the Stuart Hall School of Cultural Studies) discovered the central role played by British Art Schools in this regard. He found that the schools did a great deal to consolidate the artistic careers of musicians such as Bowie or visual artists such as Hockney. Frith's work shed light on the links between the practices of these artists at their creative zenith and the factors of class and cultural capital among students at these schools.

\section{THE MICRO-SOCIOLOGY OF CREATIVE JUDGMENT}

Marcel Duchamp, the founder of contemporary art in 1917 with his 'ready-made' (a urinal provocatively titled 'Fountain') coined the phrase "Art is a way of looking". In 1957 Duchamp defined artistic and creative experience as a form of relationship, 
without going into the substantial content of what is considered a legitimate work at a given place and time. For decades, Cultural Studies has been interested in the meaning of practices involving technology use, forming part of so-called 'cultural circuits' (Du Gay, 1997; Frith, 1986). Becker (2002) claims there is a need to innovate in the quest for new cultural and artistic realities stemming from the widespread adoption of digital tools and related technologies. At the same time, technology can be analysed in terms of gender articulation according to axes of class, race, or ethnicity (Armstrong (2011).

Cifariello (2017) analyses creativity in the distribution of musical forms mediated by technology as an object of study in itself. In short, it is a question of following what already appears in Marx, and which Rosenblum (1999: 174) expresses thus: All the post-production economic and social processes feed back into production itself, forming part of the overall production/distribution system. On the one hand, the artistic process depends on market exchange, distribution and consumption relationships. On the other hand, artists need to control the process of exchange, which involves entering the art market. Micro-analyses of everyday life (DeNora, 2014) and international comparisons of conceptual and classification categories (Fourcade, 2010) seek a practical grasp of the social categorisation of criteria and taste as classification evaluation processes. This experience is complex and, above all, collective. Moschetta and Vieira (2018) interviewed users of Spotify's music-streaming platform to analyse their new music discovery and consumption practices. They claim that while users exploit the programme's algorithms to listen to recommendations online, their first benchmark is the advice and personal recommendations of family and friends, thus the construction of musical taste remains purely social.

In addition, a direct relationship between body and music has been established over the last decade (Muntanyola-Saura, 2014, 2016). A dance sequence emerges from a host of creative and communicative micro-decisions by all those taking part in the rehearsal (that is, both dancers and the choreographer). More phenomenologically, Sennett (2012) spoke of the creativity of luthiers, giving a detailed description of their craft in the workshop, explaining their work process as a succession of both informal and embodied gestures, and formal habits. He explicitly cites the 'embodied cognition' paradigm noted by Dreyfus (1996), Clark (2008), and Gibbs (2006). He says: I will try to show how manual work can instigate dialoguebased social behaviour (Sennett: 2012: 199). Explaining how bodies interact, and determining the proximity between the mind and its biological envelope are guiding principles of current cognitive research.

To understand the construction of creativity we must therefore enter into the dynamics of interaction and communication underpinning the creation of expert categories and judgments (Teil, 2004; Hennion, 2005; Lena and Peterson, 2008; Fourcade, 2012). We use the term 'expert' in a cultural materialist sense, which is to say free from its usual elitist and individualistic social connotations. That is why we consider an expert to be someone who acts and speaks based on the terms that have been built up and conveyed within a given social sphere, such as the music scene (DelVal et al., 2014). We also move away from Essentialism by considering that expert practices and discourses change and transform depending on time and place.

This way of analysing contextualised and objectified creative practices is part of the ethno-methodological tradition. It is a methodology that has been analysing interaction processes in various institutional settings (such as hospitals, restaurants, museums, classrooms, and police stations) ever since the 1980s (Cicourel, 2002; Lieberman, 2013, DeNora, 2014, Fele, 2016, March, 2017). Ethno-methodology's starting point is to consider that judgment, evaluation, and categorisation processes are neither more nor less than spontaneous expressions of individual preferences. These judgments take place in an institutional setting, and in a specific geographical framework. There is nothing more real than what people have agreed to. What is central (from the pragmatic perspective) is the definition of the situation. Every process of knowledge and communication follows rules of 
interaction that we can observe and analyse, and that stem from the same context. Individual perceptions of the cultural object are shared, presented to the 'Other', and adjusted in a process of reciprocity that can lead towards consensus or dissent. In both cases, final judgments are inter-subjective products about subjective experience itself.

The blogging perfumers in Alac's paper (2017) develop a public language and do so by filtering and sharing their individual experience. Bloggers take the ineffability of smell as a challenge, engaging with others in an act of collective creativity. The best thing about taste or aesthetic judgment is that it transcends subjectivity by publicly sharing individual experiences within a specific vocabulary that legitimises what is being said. I attended the Venice Art Biennale last Autumn. The famous Italian pavilion designed by the artist Cuoghi presented religious figures with flowers in varying states of decomposition. The smell of flowering spores along with the varying temperature levels and the visual effect of the decomposition led to an intense experience. The whole thing proved spellbinding for the lay and expert audience, which enthused about the exhibition and took photographs. Shared comments were made about individual experiences of the installation.

The dialogue is selective. That is, when we talk about art or food we do not share all the properties of what we are contemplating or enjoying (Fele, 2016). When we are at a concert we do not blurt out all our feelings, thoughts and views to the person next to us but instead only make a few spontaneous but selective comments on our experience. In our view, the end result is that these socially validated and communicated comments may, for example, take the form of photographs shared on social networks. Indeed, most of the time conversation at work is of a multi-modal nature. In my own work on dance (Muntanyola-Saura, 2014), dancers use the term 'listening' to describe their own networking endeavours in duets and trios. They refer to a communicative posture that goes beyond speech and whose components include gaze, gestures, space, and rhythm.
We follow our own systems of relevance (Schütz, 1972), which are the product of socialisation processes based on past experiences with family and friends. Yet at the same time, the nature of the exchange, the other's willingness to listen and the sequence of the conversation shape the discourse. Creative judgment occurs at this juncture, during the conversation and does not necessarily pre-exist at the neuronal or individual level. The aesthetic act is one of shared attention, as Hennion (2005) states when talking about wine-tasting, and includes moments of inspiration and musical emotion (Green, 2016).

The ethno-methodological object, in short, appears at the moment we make a value judgment on our creative experience which, as Hennion (2005) shows, revolves around the act of paying attention. According to Lieberman (2013), participants in tasting events are not only interested in describing the taste of coffee. What they want is to share experiences, categorise and evaluate to go beyond the flavours they have already identified. They want to appreciate a given taste or nuance in greater depth, learn what it is, how to recognise it, and how to describe it. This participatory learning process raises the level of expertise. Hennion (2005) argues that taste is not socially determined but instead is an activity in which the creativity shown depends on many factors (for instance, moods, technological mediations, music circles).

\section{CONCLUSIONS}

The leitmotif of this paper is that taste judgments and creative decisions are conditioned by the positional play of consumers in relation to cultural capital, social class, sex, and age, among other factors. These factors not only construct and legitimise but also induce complexes and demobilise, fostering elitism and populism. Socially, creativity is identified with cognitive processes that take place in artistic and scientific contexts, or in the aesthetic and taste judgments made in everyday life. Taste is a form of 
discrimination, enshrining our ability to analyse, identify, recognise, and name what we perceive.

We cannot ignore the dynamics of distinction in what Bourdieu terms 'reproduction'. When the amateur perfumers studied by Alac (2017) mocked professional vocabularies, they were distancing themselves from a group of leading experts in terms of symbolic resources and cultural capital. This is a defence mechanism against the hierarchical structure of society. In this sense, there is a growing awareness of the influence of commercial interests, power, and social hierarchies in our judgments. This in turn leads to general suspicion of any hierarchy of knowledge or cultural practice that manages to legitimise itself, as well as contempt for and distrust of any notion of expertise or specialisation (Dreyfus, 1996). Recent debates over what has been called 'political populism' and 'post truth' are the fruit of these dynamics.

Creativity does not happen in a vacuum but in a specific institutional context. The institution to which we belong shapes not only the subjects we talk about but also how we talk about them. Language becomes sacred in terms of a respected vocabulary because it is linked to a social system of relevance (Schütz, 1972). The experience of creativity is not only internal but necessarily made public. This phenomenological combination leads to a change of attitude that underlies collaborative formulate criteria for cultural appreciation. Any social process involves learning, which from a Cultural Sociology perspective is rooted in primary and secondary socialisation. Learning involves specific stages, from beginners to experts, which are not random and require different criteria of cultural legitimacy and shared attention. The studies we present here collect inter-subjective processes of creation and transmission of more or less legitimate criteria on cultural consumption, categorisations, evaluations and aesthetic judgments. Sociologically, we need to know more about the attributes of the practice considered creative: the position of its producers in the social structure from whence they speak, their socialisation, their professional experience. There are theoretical precedents not only in the ethno-methodological tradition but also in the various relational approaches discussed in previous sections. In addition, a real relational stance needs to incorporate methodological and paradigmatic changes, and delve into the creative practices in their production context. Ethnographic analysis of how we pay attention to creative objects does not focus on specific attributes but rather on the dynamics of interaction and conversation. The criteria for evaluating and classifying what is good and what is bad, what has quality and what does not (and in what terms) are no longer the monopoly of experts, as we can see in the explosion of amateur bloggers, writers, photographers, science outreach, and 'likes'. It seems too that more conversation is needed if we are not to succumb to yet more marketing and populist amateurism. Here, the sociological perspective can protect us from manipulation by honing the critical tools of creativity.

\section{BIBLIOGRAPHIC REFERENCES}

Adorno, T., and Horkheimer, M. (1972/1994). Dialéctica de la Ilustración. Fragmentos filosóficos Madrid. Trotta.

Alac, M. (2017). We like to talk about smell: A worldly take on language, sensory experience, and the Internet, Semiotica, 215: 143-192

Armstrong, V. (2011). Technology and the Gendering of Music Education. Farnham: Ashgate.

Ariño, A., and Llopis, R. (2017). Culturas en tránsito. Madrid: Fundación SGAE.

Becker, H. (1982). Art Worlds. Berkeley: Berkeley University Press. 
Becker, H. (2002). Studying the New Media. Qualitative Sociology, 25-3, 337-343.

Becker, H. (2017). Creativity is Not a Scarce Commodity. American Behavioral Scientist, 6112, 1579-88.

Berger, P. and Luckmann, T. (1988). La construcció social de la realitat. Barcelona: Herder.

Bourdieu, P. (1979). La distinction. Paris: Seuil.

Bourdieu, B. (1984). Raisons Practiques. Paris: Seuil.

Bourdieu, B. (1994). Les regles de l'art. Paris: Seuil.

Brekhus, W. H. (2015). Culture and Cognition. Patterns in the Social Construction of Reality.Cambridge UK: Polity Press. Bunge, M. (2018). Diccionari filosòfic. Barcelona: Institut d’Estudis Catalans (IEC).

Clark, A. (2008). Supersizing The Mind. Oxford, UK: Oxford University Press.

Cicourel, A. (2002). The Interaction of Discourse, Cognition and Culture. Discourse Studies, 8 (1), 25-29.

Cifariello, F. (2017). "Creativitá musicale di consumo" in Fele, G.,Russo, M.,Cifariello, F. (Eds.) Creativitá musicali. Narrazioni, practiche e mercato. Milano: Mimesis.

Damasio, A. (1999). The Feeling of What Happens: Body and Emotion in the Making of Consciousness: New York: Harcourt Brace.

DelVal, F. (2017) Rockeros insurgentes, moderno scomplacientes: un análisis sociológico del rock en la Transición (19751985). Madrid: Fundación SGAE.

DeNora, T. (2014). Making Sense of Reality: Culture and Perception in Everyday Life. London: Sage.

Dennett, D. (1995). Darwin's dangerous idea. New York: Simon \& Schuster.

DiMaggio, P. (1987). Classification in Art. American Sociological Review, 52, 4, 440-455.

Dreyfus, H. (1996). The current relevance of Merleau-Ponty's phenomenology of embodiment. The Electronic Journal of Analytic Philosophy, 4.

Du Gay P (1997) Doing Cultural Studies: The Story of the Sony Walkman. London: Sage/Open University Press.

Eagleton, T. (2000). The idea of culture.London: Blackwell Publishing.

Fele, G. (2016). Il paradosso del gusto. Società mutamento politica, 7 (14), 151-174.

Feyerabend. P. (1975) Against Method. New York: Verso Books.

Feyerabend, P. (1987). Creativity: A Dangerous Myth. Critical Inquiry, 13(4), 700-711.

Frith, S. (1986). Art Versus Technology: The strange case of popular music. Media, Culture \& Society, 8, 263-279.

Fourcade, M. (2012). The Vile and the Noble: On the Relation between Natural and Social Classifications in the French Wine World. Sociological Quarterly, 53 (4), 524-545.

Gamboni,D. (2007). La destrucción del arte. Icono clasia y vandalismo desde la Revolución Francesa. Madrid: Cátedra.

Gallese, V., C. Keysers, and G. Rizzolatti (2004). A unifying view of the basis of social cognition, in Trends in Cognitive Science, 8, 396-403.

Gibbs, R. (2006). Embodiment and Cognitive Science. New York, NY: Cambridge University Press.

Green, B. (2016). I Always Remember That Moment': Peak Music Experiences as Epiphanies. Sociology, 50(2), 333-348.

Heinich, N. (1999) La sociologie et les publics de l'art in Moulin, R. (op.cit)

Hennion, A. (2005). Pragmatics of Taste. In Jacobs M. and Hanranhan, N. The Blackwell Companion to the Sociology of Culture, Oxford, Blackwell, pp.131-144.

Herrera-Usagre, M. (2011). El consumo cultural en España. Una aproximación al análisis de la estratificación social de los consumos culturales y sus dificultades metodológicas. Empíria, Revista de Metodología de Ciencias Sociales, $22,141-172$

Joas, H. (1996). The creativity of action. Chicago: University of Chicago Press.

Johnson, C; Dowd, T. and Ridgeway, C. (2006). Legitimacy as a Social Process. Annual Review of Sociology, 32, 53-78. Jacobi, D. and Luckerhoff, J. (2012). Looking for non-publics. Presses de l'Université du Québec.

Kirsh, D. (2009). Projection, Problem Space and Anchoring. In N. A. Taatgen and H. van Rijn (Eds.), Proceedings of the 31st Annual Conference of the Cognitive Science Society (pp. 2310-2315). Austin, Texas: Cognitive Science Society.

Lamont, M. (2010). Looking back at Bourdieu. In E. B. Silva, and A. Warde (Eds.), Cultural Analysis and Bourdieu's Legacy: Settling accounts and developing alternatives (pp. 128-141).London: Routledge. 
Latour, B. (1986).Visualisation and Cognition: Thinking with Eyes and Hands. In H. Kuklick (ed.) Knowledge and Society Studies in the Sociology of Culture Past and Present, Jai Press 6: 1-40.

Lena, J. C. and Peterson, R. A. (2008). Classification as Culture: Types and Trajectories of Music Genders. American Sociological Review, 73 (5), 697-718.

Lieberman, K. (2013). Studies in Ethno-methodology: Studies of the in vivo organization of sense. State University of New York Press.

Lipovetsky, G. (2007). Le bonheur paradoxal. Essaisur la société d'hyper consommatiom. Paris: Gallimard.

Lipovetsky, G., and Serroy, J. (2015). La estetización del mundo. Barcelona: Anagrama.

Lizardo, O. (2004). "Mirror Neurons," Collective Objects and the Problem of Transmission: Reconsidering Stephen Turner's Critique of Practice Theory.Journal for the Theory of Social Behaviour, (37)3, 219-350.

Lizardo, O. (2004). The Cognitive Origins of Bourdieu's Habitus. Journal for the Theory of Social Behaviour, 34 4, $375-401$.

Lizardo, O., and Strand, M. (2010) Skills, Toolkits, Contexts and Institutions: Clarifying the relationship between different approaches to cognition in Cultural Sociology. Poetics, 38, 204-227.

López Sintas, J.L.; Filimon, N., Cebollada, A. Filimon, N., and Gharhaman, A. (2014) Music Access Patterns: A social interpretation.Poetics 46, 56-74.

Mas, X. (2017). La música clàssica contemporània: una perspectiva etnomusicològica. Sociology PhD thesis, Universitat de València.

Merton, R.K. (1945). Sociological Theory. American Journal of Sociology, 50 6, 462-73.

Moschetta, P.H., and Vieira, J.S. (2018). "Music consumption in the streaming era: Music curation practices in Spotify", KISMIF Congress 2018: Gender Differences, Identities and DIY Cultures Universidad de Porto, 2nd-3rd July.

Moulin, R. (Ed.) (1999).Sociologie de l'art. Paris: L'Harmattan.

Muntanyola-Saura, D. (2012). La decisió artística i les seves condicions de producció: parlant amb un equip de rodatge. Athenea Digital,12(2): 89-109.

Muntanyola-Saura, D. (2014). How multi-modality shapes creative choice in dance. Revista Española de Sociología, 72(3), 563-582.

Muntanyola-Saura, D. (2016). La musicalidad como parte de la cognición distribuida en danza. Methaodos. Revista de ciencias sociales, 4(1), 163-175.

Premack, D. (2004). Is Language the Key to Human Intelligence? Science 303, 318-320.

Ramachandran,Vilanayur S., and Blackeslee, S. (1999). Phantoms in the Brain: Probing the Mysteries of the Human Mind. NewYork: William Morrow.

Regev, M. (2013). Pop-rock Music. Aesthetic Cosmopolitanism in Late Modernity. Cambridge UP.

Rendueles, C. (2013). Sociofobia. El cambiopolítico en la era de la utopía digital. Madrid: Capitán Swing.

Rosenblum, B. (1999).Artists, Alienation and the Market in Moulin (op cit.).

Searle, J. (2004). Mind. Oxford University Press.

Sennet, R. (2012). Together. London: Penguin Books.

Schütz, A. (1972). Collected Papers vol. I. The Netherlands: Springer.

Stuart Hall, E. (2007). Richard Hoggart, The Uses of Literacy and The Cultural Turn. International Journal of Cultural Studies, 10(1), 39-49.

Stuart Hall, E. and Jefferson, T. (eds) (1998 [1975]). Resistance Through Rituals: Youth Sub-cultures in Post-War Britain. London New York: Routledge.

Teil, G. (2004). De la coupe aux lèvres. Pratiques de la perception et mise en marche des vins de qualité. Toulouse: Éditions Octarès.

Vandenberg, T. et al. (2018). "Taste patterns of the 'illegitimate' cultural consumer", KISMIF Congress 2018: Gender Differences, Identities and DIY Cultures Universidad de Porto, 2nd-3rd July.

Vlegels, J. and Lievens, T. (2017). Music classification, genres, and taste patterns: A ground-up network analysis on the clustering of artist preferences, Poetics 60, 76-89.

Williams, R. (1992 [1958]). Culture and Society. London: The Hogarth Press. 


\section{BIOGRAPHICAL NOTE}

\section{Dafne Muntanyola-Saura}

She has a PhD in Sociology (2008) from Universitat Autònoma de Barcelona (UAB) at which she is a Lecturer. Muntanyola-Suara was an FPU scholarship student, a Caja Madrid scholarship at Université de Nice, and Fulbright Scholar at the Department of Cognitive Sceince at The University of California, San Diego (UCSD), and Lecturer at Universidad Autónoma de Madrid (UAM). Her interdisciplinary research covers interactive communication processes in artistic circles involving a component of audiovisual methodology and analysis of social networks. 


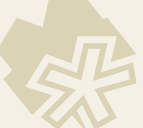

